\title{
INCREASING TAX-TO-GDP RATIOS OF SUB SAHARA- AFRICAN COUNTRIES: LESSONS FROM ADVANCED ECONOMIES
}

\section{Prof. E.O. Nwadialor, and Elias Igwebuilke Agbo}

Department of Accounting and Finance, Faculty of Management and Social Sciences, Godfrey Okoye University, Ugwuomu-Nike,Emene, Enugu State, Nigeria.

E-mail: agboelias@ymail.com

profnwadialor@gmail.com

\begin{abstract}
This study has the objective of identifying the challenges militating against the growth of tax-to-GDP ratiosof sub-Sahara African countries, their causes and remedies. Nigeria is used as a case studywhile the content analysis research approach is adopted.Reports from some apex international monetaryauthorities indicate that, while a typical advanced country has a tax-to-GDP ratio of around 40\%, manysub-Sahara African countries maintain tax-to-GDP ratios that fall below the $15 \%$ threshold..Though the tax structures in many of thosecountries have improved in recent times, growth in their domestic revenue mobilization has been generally sluggish.Many of them persistently experience significanttax-gaps,overwhelming incerase in external debt-to-GDP ratio and budget deficits - a clear manifestationthat their tax policiesrequire serious overhauling. The paper reveals that the low- rated countries are characterized by Gulf countries while the high rated ones are dominated by European countries and that, even as one the largest economies in Africa, Nigeria is one of the subSahara African countries having the lowest tax-to- GDP ratios. It suggests that, in line with best practices, thesub-Sahara African countries should put in place clear political mandates to tackle low levels of tax payment and a simpler tax system with a restricted number of rates and exemptions.
\end{abstract}

Keywords: Tax-to-GDP Ratio,Taxation,Tax gap, Gross Domestic Product, Nigeria, SubSahara Africa.

\subsection{Introduction}

Sub-Sahara African countries generally face a shortfall in providing finance for investment. The amount of shortfall is estimated at approximately $\$ 230$ billion a year and expected to continue to remain so in the next five years(Coulibaly \& Ghandi,2018).This shortfallarises from low domestic savings rates, partly as tax revenue collection continues to be low. According to Coulibaly \& Ghandi,even though tax revenues in the region (excluding those raised from the natural resource sector) moved up from 11 percent of gross domestic product (GDP) in the early 2000s to about 15 percent in 2015, the ratios are stll below the desired level, the levels of the Organization for Economic Development and Cooperation (OECD) (24 percent) and other emerging and developing countries.

It might appear that the tax structures in many of those countries have improved in recent times; however, growth in their domestic revenue mobilization has been generally sluggish. Many of them persistently experience significant tax-gaps, disproportionate increase in external borrowing and budget deficits - a clear manifestation that their tax policies require 
serious overhauling.Filling this large tax gap with external financing alone will translate to substantial current account deficits in those countries and subject their economies to balance of payment crises in addition to macroeconomic instability.Further,as the prospects for external financing looks increasingly more difficult, and with debt levels on the rise across the region, the mobilization of domestic resources is now a necessity. After carrying out a study on this issue, IMF (2019) has reported that,despite an overall increase in their economic growth, the sub-Sahara African countries are at a growing risk of debt distress because of heavy borrowing and gaping deficits. The apex international monetary authority advises that, henceforth,the sub-Sahara African countries need to be relying on sustainable sources of financing, more so as debt vulnerabilities continue to rise in the region.This strategy will work if the nations make domestic revenue mobilization one of their most urgent policy thrusts.

Given the scenario highlighted above, the importance of boosting domestic resources, which hold the key to Sub-Sahara Africa's ability to sustainably finance its development agenda can hardly be overemphasized..Cosequently, this study is motivated to seek to identrify the challenges militating against the growth of tax-to-GDP ratios of sub-Sahara African countries,their causes and remedies..Nigeria is selected as case study because of the position she occupies not only as one of the largest economies in the region but also the country having one of the smallest tax-to-GDP ratio in not only sub-Sahara African region but also theentire universe.

The remaining part of thispaper is organized as follows: Section 2 presents the summary of the literature related to the topic. Section 3 highlights the major challenges militating against increasing the tax/GDP ratio ofsub-Sahara African countries. Section 4 suggest the remedies while Section 5 concludes the paper.

\subsection{Review of related literature}

\subsection{Conceptual and contextual review}

\subsubsection{The concept of tax}

Tax has been given alternative definitions by different individuals.For instance, theInstitute of Chartered Accountants of Nigeria [ICAN](2009) defines tax as an obligatory contribution imposed on the citizens by the government in order to provide social services and to ensure the citizens' social and economic welfare. The National Tax Policy for Nigeria considers tax as a monetary charge on a person's or entity's income, property or transaction and is usually collected by a defined authority at Federal, State or local level.For Obatola (2013), tax is an obligatory levy imposed by government or any recognized authority of the state on the property, goods, services and people living in an area for revenue generation to offset the expenses incurred by the government or the authority on behalf of the citizens. Some others ragard tax as a fiscal policy tool employed by government to redistribute wealth or to achieveother macroeconomic objectives; they treat tax as a fiscal tool used for stabilizing an economy.

As many as the definitions above and other similar definitions may be, there exists some common basic elements in them.For instance,they all consider tax as a compulsory levy imposed by the government on its citizens and business entities to raise fund utilized to finance government operations.

Tax revenues are essentially the revenues collected from income taxes, social security contributions, value added tax, payroll taxes, and other items. Social security payments, fines, and penalties are usually excluded from its calculations.

Tax is a major source of government revenue which serves not only as a means for financing 
government expenditure programs but also as an essential measure of economic stabilization policy.Some people may regardtaxes asunequitable as government will always desire to collect more while the taxpayers might not necessarily be the direct beneficiaries of their tax contributions.

But for few tax heaven countries where taxes are not charged at all and other rich Gulf countries where the rate of taxes are low, taxes are collected in almost all countries. In jurisdictions where taxes are not imposed, or are levied at minimal levels, such policies are usually adopted for a given period with the anticipation that when certain level of development or conditions are met, taxes will be imposed accordingly.Such policies are used to encourage investment in some sector/s of the economy. Policies like this come in the form of tax reliefs which are generally referred to as tax expenditures.The tax reliefs or allowances in this case are akind of government's indirect spending to finance some particular areas of government priority.

\subsubsection{Tax Policy}

Governments in many countries direct theireconomies through monetary and fiscal policies.Tax policy belongs to an aspect of fiscal policy measures.Tax policyrefers to government's decision to change the level of revenue (tax) and government spending as well as the management of the balance arising from the difference between the two. Stabilization policy measures, which include taxation, are used to regulate economic activities in an economy in the pursuit of the goal of accomplishing macroeconomic stability. However, painful tradeoffs usually arise as one fiscal policy tool, when implemented, may lead to some undesirable macroeconomic effects that are in conflict with some other macroeconomic objectives.

\subsubsection{Tax Gap}

Mazur \& Plumley(2007) define the term"tax gap as"as the difference between the total tax imposed by the Tax Code and the amount which is reported and paid with timely filed returns. Equally, Fiscalis Tax Gap Project Group (2018) defines the corporate income tax gap as the gap between corporate tax revenues as they should be collected and as they are collected.. Generally,tax gap is understood to mean the difference between total amounts of taxes owed to the government versus the amount they actually receive.It is an indication of potential tax revenue losses. Usually, a tax gap is caused when taxpayers overstate their deductions and understate their taxable incomes in a bid to pay fewer taxes. Late payment of taxes by taxpayers also causestaxgaps. Theoretically, the concept covers all taxpayers and all taxes.

There are two major approaches for estimating the tax gap - the top-down and bottom-up methods .Each of the two approaches has some merits and demerits. The choice of the estimation method depends seriously on the nature of data, resources and purposes of the estimate.However, it has been identified that the best strategy is to adopt the approach that taps from each of the two alternatives.

\subsubsection{Gross Domestic Product (GDP)}

Gross Domestic Product is the market value of all final goods and services produced within a country in a given period. It measures the net output or value added as it measures goods and services bought with money.A boostin the annual output of goods and services in a country could be described as economic growth. This could be measured using Gross Domestic Product (GDP) or Gross National Product (GNP).Economic growth is said to have 
taken place in a nation when the latter's GNP or GDP becomes larger than what it was. It is the rate of change of real income or real output. GDP measures the total output and sum total income of an economy at a given period respectively.It is one of the important indicators of a country's economic health, showing how big the economy is. It can also be used to compare the earning and spending capabilities of different countries. The increase should be steady and sustained for at least two successive quarters; hence, economic growth could be described as a steady increase in the output of final goods and services.

In some situations, economists take theimpact of inflation into consideration in the measurement of economic growth;. When that is the case, the outcomeis termed 'Real GDP'. It is argued that by relating the GDP to the population a better picture of the welfare of the citizens are presented.This has resulted in the use of the term GDP per capita.

The concepts of actual GDP,potentialGDP and GDP gap or output gap have been aptly described by Lipsey and Chrystal (2011).The authors refer to actualGDP as what the economy actually produces and potential GDP as what the economy would produce if all the resources [ land, labor and productive capacity] were fully employed at their normal level of utilization. This is also referred to as potential income orfull-employment income (highemployment income).GDP gap is the difference between the actual and potential GDP.

\subsubsection{Tax -To-GDP - Ratio}

Table 1 and figure 1 , both in appendix A, show the average values of tax- to-GDP ratios of fifteen lowest and fifteen top rated countries. Table 1 shows the Tax- to-GDP ratios of the fifteen countries with low tax-to-GDP ratios and another set of fifteen with high tax-to-GDP ratios. The low- rated countries are characterized by Gulf countries while the high rated ones are dominated by European countries.Both of them show that Nigeria is ranked the 13th lowest amongthe countries with low tax-to-GDP ratio. A look at the countries in the lower ranks will disclose that the list contains the Gulf Countries that are usually characterized by low tax rates. These countries are considered rich with manageable population size.Thus, the oil revenue has made them rich and the revenue generated from oil sectors in the Gulf States have been put into infrastructural development and investments. Examples are the United Arab Emirates, Qatar and the Saudi Arabia. These countries do not focus on tax revenue.For thatreason, they havelow tax-to-GDP rates. Figure 2 shows the chart of the top 15 Countries with high tax rate to GDP ratio. The country with the highest tax-to-GDP ratio considered in this study is Algeria. The country has a high tax- to= GDP rate of $64 \%$, even when the country is also an oil producing state. Most of the countries with this type of tax-to-GDP ratio are developed countries. Over $80 \%$ of the countries in this category are European countries. The deduction from this is that the European economy is tax-driven and it is mostly made up of non-oil producing state.

\subsubsection{The tax-to-GDP Ratios of Sub-Sahara African Countries.}

According to Heritage Foundation(2015) cited in the Wikipedia(2019), the Sub-sahara African countries and their tax-to-GDP ratios include Angola (10.33\%), Benin (15.4\%), BokinaFaso(11.5\%), Botswana(35.2\%),Burundi(17.4\%), Cameroon (10.2\%), Cape Verde (23.0\%),Chad(4.2\%), Central African Republic (8.7\%), Colombia(16.1\%), Comoros (12.0\%), Cote d'Ivoire (15.3\%), Democratic Republic of Congo(13.35);Djibouti (20.0\%); Equatorial Guinea(1.7\%); $\quad$ Eritrea(11.50\%),Etheopia(11.6\%),Gabon(10.3\%), Gambia(18.9\%), Ghana (20.8\%), Guinea (8.2\%), Guinea-Bissau (11.5\%), Kenya (18.4\%), Lesotho (42.9\%), Liberia (13.2\%), Libya(2.7\%), Madagascar (10.7\%), Mali (15.3\%);Malawi (20.70\%), Mauritania (15.4\%), Mauritius (19.0\%),Mozambique (13.4\%), Namibia (28.8\%), Niger (11.0\%), Nigeria 
(6.1\%), Republic of Congo (5.9\%), Rwanda (14.1\%), Sao Tome and Principe (17.4\%),Senegal (19.2\%); Sierra Leone (10.5\%), Seyechelles (32.0\%), South Africa (26.9\%), Sudan (6.3\%), Swaziland (39.80\%),Tanzania (12.0\%),Togo (15.5\%), Uganda (14.2\%), Zambia (16.1\%) and Zimbabwe (27.2\%).

Based on the statistics above, the sub-Sahara African countries having tax-to-GDP ratios that fall below the $15 \%$ threshold include Libya(2.7\%), Chad(4.2\%), Republic of Congo (5.9\%), Nigeria (6.1\%), Guinea (8.2\%),Central African Republic (8.7\%),Cameroon(10.2\%),SierraLeone(10.5\%),Niger(11.0\%), Guinea-Bissau(11.5\%), Bokina Faso (11.5\%), Comoros (12.0\%), Tanzania (12.0\%), Liberia (13.2\%), Democratic Republic of Congo(13.35\%),Mozambique (13.4\%), Rwanda (14.1\%) and Uganda (14.2\%),

Nigera is the fourth country wth the lowest tax-to-GDP ratio.Though Nigeria is also an oil producing state, it has higher population level but poor infrastructure.The Nigerian government understands the importance of tax revenue and has a policy aimed at moving away from oil based-revenue to tax revenue. However,she has not been able to significantly grow its tax-to-GDP ratio.

\subsubsection{Nigeria's Tax-to-=GDP Ratio in Comparison wth thse of other African Countries}

Figure 3 in appendix B shows the bar chart of selected African countries and OECD average. Algeria which has world highest average tax-to-GDP rate is from Africa. Amongst the big African economies,Nigeria ranked lowest with respect to tax-to-GDP ratio even when the country has higher GDP value and is considered as the largest economy in Africa.In terms of tax revenue, her performance is very poor as shown by the tax-to-GDP ratio for the respective years. Only three countries in Africa are comparable to OECD tax to GDP rate. The lower tax proportion has affected a sustainable growth in the economy as shocks affecting oil prices which is the major source of revenue to the government throws the economy into crises.Nigeria's tax to GDP ratio is reported to have been between 5\% and 6.1\%. as against the West African Regional average of $15 \%$ and the Asian average of $22 \%$ and OECD average of 27\% (see International Monetary Fund, 2018). Recent data from the National Bureau of Statistics indicate that Nigeria's GDP stood at $\$ 31.79$ trillion during the first quarter of 2019 (Q2 2019) while the total government collection in taxes was only $\$ 1.5$ trillion in that quarter(Kolade\&Ajogbor,2019).

Concerning tax-to-GDP ratio, World Bank(2018) reports that a typical advanced country has a tax to GDP ratio of around $40 \%$.However, many developing countries have a low tax-toGDP ratio and about 60 countries fall below the 15\% threshold.Based on World Bank's measurement, Nigeria's tax-to-GDP ratio in 2016 was just 3.4\%. The ratio improved in 2017 to $4.8 \%$, according to the figures provided by the Nigerian authorities. This could be explained partially by the lower international oil prices and the recession experienced by the Nigerian economy in 2016. For instance, the average price of crude oil fell from about $\$ 113$ a barrel in 2012 to just over $\$ 54$ in 2017. Between 2012 to 2014, the oil sector provided 57\% of total Nigerian government revenue. This percentage fell to $41 \%$ between 2016 to 2018 . Also, based on the 2019 UN report in 2018, Nigeria's estimated VAT gapwas one of the largest in Africa.

Iyalode (2019) observes that Nigeria'stax-to-GDP ratio is significantly smaller than those of Ghana and Egypt, Morocco and South Africa which are 16 percent, 22 percent and 27 percent respectively(Iyalode,2019), Iyalode cosiders the challenges discouraging Nigerians from being tax-compliant as high tax rates, segmentation and valuation criteria, collection, multiple taxation and inefficient utilization of the funds generated from tax. Oluseye Arowolo, a partner with Deloitte \& Touche Nigeria revealed that only 214 Nigerians paid up 
to 20 million Naira as annual tax, 914 people paid up to 10 million Naira while 14 million were tax payers registered under the Pay -as -You - Earn system. He added that only 70 million were economically active individuals and that, based on the information provided by the Corporate Affairs Commission, there were only 2.5 million tax-registered corporates while only 30 million on their list.

Table 2 in appendix $\mathrm{C}$ shows the statistics of real GDP, Tax revenue and Tax-to-GDP ratios from year 2004 to year 2019. The average value of GDP from year 2004 to 2018 is 55264.19 billion that of tax revenue is 3347.532 while that of tax revenue-to-GDP is 5.86. This implies that about $94.2 \%$ of contribution to GDP within the period was from other sources of revenue like the oil sector. This implies that any factor affecting the other sources of revenue like oil price fluctuation will significantly impair the level of economic growth of the country. The standard deviations of the variables are also high. This implies lack of stability in growth of GDP and Tax revenue. Without a stable growth, and stable revenue flow the economy will seriously be affected. The volatility value of Tax-to-revenue growth is low which also implies that no serious effort was made towards increasing the rate of Tax revenue-to-GDP since the volatility rate is low.

Table 1 shows the annual GDP values, total tax revenue and the tax- to- GDP ratio whilefigure 4 in appendix D presents the graph of GDP growth and total tax revenue growth rate from year 2004 to 2018. The graph in figure 4 depicts that for the majority parts of the years the growth value of GDP and that of Tax revenue move in the opposite directions. This implies that there is co-movement of the two which is against theoretical expectations. However, a rational explanation of this is that when even there are sufficient revenue flow from other sources such as oil revenue less effort is given to tax revenue. It can be observed that from the year 2014 ending the GDP growth rate decreased to negative growth while the tax revenue grow higher compared to GDP. This is also the period when emphasis was given to tax revenue as a result of decline in oil revenue. However, with increase in oil prices from the middle of 2017 the GDP rate surpassed that of tax revenue growth.

Figure 5 shows the movement in the rate of tax revenue to GDP. The movement shows that there is high level of instability in tax performance with respect to GDP. It implies that efforts made to improve tax revenue subsequently reversed back to previous position or even worse. The highest contribution of tax to GDP was in the year 2012 when it went as high as $8.35 \%$. The rate later declined until the year 2016 when it continued to grow.

\subsection{Theoretical Franework}

\subsubsection{Models of Taxation}

There are several theories of taxationin public economics.

Two main issues have existedin tax administration. The issues bother on identifying who can pay as against who can benefit. While the ability theory was propounded by Arthur Cecil Pigou, the benefit theory was developed by Erik Lindahl.Another version of the benefit theory was developed after that of Lindahl; it is known as the voluntary exchange theory.

The benefit theory demands that tax levels be automatically determined since taxpayers pay in proportion to the government benefits that they receive. This means that the individuals who benefit more from public services should pay higher taxes.

The two approaches in sympathy with the benefit theory are the Lindahl model and the Bowen model.

\subsection{1(a) Lindahl model}

Lindahl model attempts to solve three problems including the extent of state activity, the 
allocation of the total expenditure among various goods and services and the allocation of tax burden.There is a theory called Lindahl equilibrium.It advocates that individuals pay for the provision of a public good in accordance with the marginal benefits they enjoy so as to determine the efficient level of provision for public goods. Under this model, all individuals consume the same quantity of public goods but may have to pay different prices because some of them may value a particular good more than others. The Lindahl equilibrium price is the amount an individual pays for his or her share of the public goods.

\subsection{1(b)Bowen's model}

This modelassumes that when social goods are produced under conditions of increasing costs, the opportunity cost of private goods is foregone.It appears to be possessing more practical significance,

Advantages and limitations of the benefit theory

Although the benefit theory has the advantage of ensuring the direct correlation between revenue and expenditure in a budget and in approximating market behaviour in the allocation procedures of the public sector, its application has some challenges. For instance,

- $\quad$ it reduces the extent of government activities.

- its application disenables Government to either support the poor or take steps to stabilize the economy.

- $\quad$ it is applicable only if the beneficiaries can be observed directly- an exercise which is impossible for most public services, and

- $\quad$ if taxation is to be in accordance with the benefit principle, the distribution of real incomes will be left unchanged.

\subsection{1(c)Ability-to-pay Theory}

The ability-to-pay theory considers public revenue and expenditures separately. Under this approach,taxes are imposed based on taxpayers' ability to pay; there is no quid pro quo. The taxes paid are considered as a sacrifice by taxpayers. This is the most popular and commonly accepted principle of equity or justice in taxation as it provides that citizens of a country should pay taxes to the government in accordance with their ability to pay.

It seems that if the taxes are levied on this principle as stated above, then justice can be achieved. However,the problem arises with the definition of ability to pay as economists are not unanimous as to what should be the exact measure of a person's ability or faculty to pay; that is, whether it should be equal sacrifice, equal proportional sacrifice,or equal marginal sacrifice.

\subsection{1(d) The Cost of Service Theory}

This theory proposes that if the State recovers the actual cost of the service rendered from the people in the form of tax, it will satisfy the idea of equity or justice in taxation. The cost of service principle appears a bit easy to determine. However, majority of the expenditure incurred by government cannot be fixed for each individual because it cannot be exactly determined. For instance, the cost of service of the police, armed forces or judiciary can not be precisely aqpportioned to different individuals.

\subsection{1(e) Proportionate Principle}

In order to provide for the idea of justice in taxation, some classical economists suggest the proportionate principle. The proponents of this theory are of the opinion that if taxes are 
levied in proportion to the incomes of the individuals, that will extract equal sacrifice. However, the economists opposed to this theory contend that when income increases, the marginal utility of income decreases. They argue that the equality of sacrifice can only be achieved if the persons with high incomes are taxed at higher rates and those with low income at lower rates . In other words, they support the progressive system of taxation.

This paper is anchored on both the ability to paytheory and the progressive system of taxation.

\subsubsection{Characteristics of a goodtax system}

According to Adam(1776), a good tax must meet the following major criteria:-(i) The tax has to be proportionate to incomeand affordable (ii) It must be certain rather than arbitrary.(iii) It must be payable at times and in ways convenient to the taxpayers and (iv) It has to be cheap to administer and collect. The scholars of the modern times are not unanimous on what should constitute the characteristics of a good tax system. That notwithstanding, the following are considered by many as the properties of a good tax system:-

\section{(a)Fairness or equity:}

A good tax system should be fair or equitable in distribution. Thus, individuals in similar financial condition should pay similar taxes. This is referred to as horizontalequity. The principle ofhorizontal equity also demands that individuals with the same income but different allowable expenses pay different amounts as tax. In contrast,vertical equity requires that persons who are financially advantaged over others should pay at least the same proportion of income in taxes as those who are not well off.Under this system, taxes are classified as regressive,progressive orproportional. A tax system is regressive when those with lower incomes pay a larger share of income tax than those with higher income. This is common to taxes on necessities such as food items as lower income earners spend much of their income on them. Tax is appliedat the same rate to most corporate income. Tax system is progressive when higher income individuals pay higher share of their income in taxes as typified by Federal Income Tax.

(b)Adequacy.Atax system should be able to provide adequate revenue that meet the basic needs of the society. Public services are funded from tax; hence as the demand of the public increases, it is expected that the revenue generating activities should grow accordingly to make the tax rate stable or relatively low.

(c)Transparency.This connotes that the tax payers and the public authorities can easily access information about the tax system and how the tax revenue has been spent. A transparent tax system readily provides information on who is being taxed, how much is collected and what the money is used for.

d)Simplicity.Tax system should be simple for the tax payers to understand.This reduces the cost of compliance. It implies that the tax, tax forms and tax filing process should be simplified.

(e)Administrative ease. The tax system should not be complicated or costly for either the tax payer or the collector. The rules should be made known and simple;the tax forms should be simplified. The cost of collection should be small relative to the amount collected. Audit should be fairly conducted. 


\subsubsection{Why we pay taxes}

The issue of tax and its payment is as old as mankind.Right from the commencement of creation up to this moment, tax has mattered so much. The fiscal social contract between citizens and elected leaders implies that citizens should pay tax which the leaders will utilize to execute programs for their collective good. Taxes are also paid because it is a legal requirement.

How persons and businesses react in turn affects the echelon and organization of taxation.Tax is a compulsory levy by a public authority for which nothing is received directly in return. It is, therefore, an obligatory contributionenforced by government. While taxpayers may receive nothing substantial in return for their contribution, they nevertheless have the advantage of living in a relatively educated, healthy and secure society.In other words, tax is part of the price to be paid for an organized society for the provision of social amenities, redistribution of income and wealth, promotion of social and economic welfare, economic stability and coordination and regulation (see James \& Nobes, 1992; Nightingale, 2001).

The first detailed historical information about taxation can be found in Ancient Egypt. It was said that Pharaohs selected tax collectors (called scribes) and paid them high salaries to reduce the incentives for them to enrich themselves. Furthermore, scribes working in the field were monitored by a group of special scribes from the Kings Palace (Webber \& Wildavsky, 1986). The essence was to eliminate corruption in the collection of tax. Sadly however, corruption of the tax agency is still a problem, especially in developing countries.

\subsubsection{Objectives of Taxation}

In agreement with the view of Muley (n.d), the major objectives of taxation comprise the following:-

(a) Revenue Generation:

The major objective of taxation is to generate income for the government to finance the general administration and other projects of the government These may not be profit yielding but have indirect link with economic growth and development. The essence of taxation is therefore to raise money needed to satisfy the need of government in the provision of services like defense, law and order, health services and education. Capital projects also benefit from the revenue generated.

Such projects improve social and economic infrastructure such as road, railways, bridges, etc. (b) Redistribution of Income and Wealth. This could be seen from the doctrine of taxation known as the 'Ability to Pay' which implies that the burden of taxation ought to be heavier on the affluent member of the society than the poor (progressive tax system). This is based on the understanding that the concentration of nation's wealth in the hands of few is unjust ; hence the need to redistribute it. High tax on the income of the rich can have incentive or disincentive effect as tax reduces income and can spur the individual to work harder.

(c) Management of the Economy.Taxation is essential in planning savings and investments by harmonizing same with development strategy and changing economic structure. This may be in the form ofeconomic development,full employment,control of cyclical fluctuations, reduction in balance of payment difficulties, price stabilityand harmonization of trade among nations through tax treaties.

\subsubsection{Tax Evasion and Tax Avoidance}

Tax evasion is a deliberate or preconceived act or designby the tax payer with intention ofreducing their tax burden. It is a criminal act which, in addition to fines and penalties, may 
lead to imprisonment.

According to Bassey (2013), tax evasion includesomitting or understating the income liable to tax, overstating expenses so as to reduce taxable income, claiming reliefs and deductions which the tax payer is not entitled to,failing to pay tax as due or failure to remit withholding tax and PAYE deductedand failing to file returns with the relevant authority or submission of false or incorrect return.

On the other hand, the following constitute acts of tax avoidance:-exploiting the loopholes existing in the tax laws, thin capitalization where the tax payer decides to use more loans than equity to operate and where there are optionsthe tax payer can take which benefits him/her,

\subsubsection{Tax -To-GDP - Ratio}

Kagan (2019) defines tax-to-GDP ratio as a ratio of a country's tax revenue relative to its gross domestic product. According to the author,taxes and GDP are correlated. The higher the GDP, the more tax a nation collects. Conversely, countries with lower taxes produce lower GDPs. Analysts, economists, and public authorities can use this ratio to discover the rate at which taxes fuel a nation's economy.The tax-to-GDP ratio is usuaally employed in conjunction with other metrics to measure how much a country's government controls its economic resources.

. It is usual for countries having higher GDP to collect more taxes, while those with lower taxes also emerge with a lower GDP(seeKagan,2019). Kagan asserts thatwhen a nation's tax revenues grow at a slower rate than its GDP, the tax-to-GDP ratio drops; but, if tax revenue grows quicker than the GDP, the ratio will increase.According to Oladipo \& Ogochukwu( 2019), however, the ratio of tax-to-GDP remains consistent as tax is closely related to the level of economic activity. Even though the tax-to-GDP ratio is nothing more than the portion of a nation's output that is attributable to tax receipts, it is one of the most widely used tool for measuring the efficiency of a country's tax system.

GDP is calculated by summing up consumption expenditures such as durable and nondurable goods, services, and investments including business fixed, residential, and inventory investments and government purchases and subtracting from the total the net exports for the country.

\subsection{Review of the related Literature}

Numerous studies haveinvestigated the correlation between tax revenue and economic growth. Examples of such studiescarried out in Nigeria include Oyewo (2013), Anokoya and Afinkinni (2016), Ezeji.Chigbu and Ali (2014), Lawrence (2015) and Manukaji \& Nwadialor(2016)(see Abdulazeez and Dandago,2018).

For instance, Oyewo (2013) examined the tax incentives currently available in the different tax laws. The author also evaluated how taxation and tax policies have affected the Nigerian economy as well as the effectiveness of taxation as a government strategy tool for the Nigerian economic development. The study used time series data of taxation and economic development of the period 1960 to 2007 and correlation, time series and multivariable regression to analyze the relationships among variables. The results of the study show that taxation and tax policies contributepositively to economic development.

In a related study,Ezeji, Chigbu and Ali(2014) invstigated the importance of value added tax (VAT) as a source of government revenue in both developed and developing countries with the objective of empirically finding out the relationship between VAT and economic growth in Nigeria. Using the Engle and Granger co-integration technique on annual data sample covering 1994 to 2012, the paper demonstrates that VAT has positive effect on economic 
growthproxied by real GDP. The results also show the absence of both long-run and short-run relationship between VAT and GDP.

Lawrence(2015) equally carried out a study in Kenya to determine the effect of value added tax on economic growth using the causal study research design. The target population for this study comprized the quarterly reports on the state of the Kenyan economy in relation to productivity. The study proxied productivity by Gross Domestic Product (GDP), consumer prices by consumer price indexes (CPI), and employment by the unemployment rate. The scope of the paper covered from 1990-the inception of VAT as administered by Kenya Revenue Authority (KRA) to 2014. It employed secondary data made up of VAT rates, gross domestic product growth rates, consumer price indices and unemployment rates which were retrieved from Kenya Revenue Authority (KRA), International Monetary Fund (IMF), Kenya National Bureau of Statistics (KNBS) and The World Bank data bases respectively. The results of the study indicate that there exists a significant negative relationship between VAT rates and GDP.

In addition,Folajimi,Olajumoke and Jayeoba(2016) assessed the impact of VAT on Nigerian economy from 1994to 2015 with the purpose of discovering the imperativeness of its reform. Ex-post-facto, descriptive and analytical research approaches were employed for the study. The results of the study indicatethat VAT has a positive relationship with GDP. The coefficients of the model indicate that a $1 \%$ increase in VAT will lead to a $0.88 \%$ increase in GDP.

In a more recent period,Okwara and Amori(2017) investigated the impact of tax revenue on the economic growth in Nigeria for the period of 1994-2015, using secondary data sourced from journals, textbooks and CentralBank of Nigeria $(\mathrm{CBN})$ statistical bulletin. Ordinary Least Squares (OLS) wasused to test the significant impact of value added tax and non-oil income on Gross Domestic Product (GDP). The results show that non-oil income has significant impact on gross domestic product while value added tax has negative and statistically insignificant relationship for the period under review.

Another study in this dimension was Odhiambo and Olushola(2018). The authorsinvestigated the correlation between taxation and economic growth in a resource rich country, using Nigeria as a case study. The study was aimed atascertaining the connections existing between availability of higher resource revenue and lower taxation effort of other revenue groups and their effects on growth. It employed Ordinary least squaresestimationtechnique in estimating the specified model. Empirical results show that taxation has a significant impact on real GDP growth rates but the proportion of tax contribution to the growth rate is not up to the optimal level in terms of the volume of economic activities and value of total output

Most resently,Eze, Udude and Atuma (2018)investigated the impact of tax policy on economic growth in Nigeria for the period 1981-2015. Auto Regressive Distributed Lag (ARDL) test and Pairwise Granger causality test were employed in the analysis. The variables utilized in the study are real gross domestic product, personal income tax,companies income tax, government expenditure, exchange rate, broad money supply and interest rate . The results of ARDL test show evidence of both long run and short run relationships among the variables and that personal income taxhas positive and insignificant impact on real GDP whilecompanies income tax has negative and significant impact on real GDP.

During the same year,Kalaš, Mirović and Milenković(2018) carried out an empirical analysis of taxes and economic growth in Serbia and Croatia in respect of the period 2007-2016so as to identify the impact of tax forms on economic growth and their relationship. The authors 
employed panel regression where gross domestic product was the dependent variable, while corporate income tax, value added tax, social security contributions and excises were the independent variables. The results of the random effect model used in analysis show that corporate income tax, value added tax and social security contributions have a positive have on the gross domestic product, while excises has a negative impact on the gross domestic product. The results of the study also indicate that only value added tax has a statistically significant impact on economic growth in the two countries, with each increase in revenue from this tax contributing to the growth of gross domestic product during the study period.

In a related study,Ubesie, Igweonyia and Ozo-Ubaka (2019) empirically examined the causal and long-run relationships between taxation and economic growth of Nigeria. The study spanned from 1994 to 2017 and employed annual time series comprising secondary data extracted from the Central Bank of Nigeria (CBN) statistical bulletin (2017) edition. Ex-post facto research design was adopted while the Vector Autoregressive (VAR) method, Pair-wise Granger Causality test and Vector Error Correction Mechanism (VECM) were employed for analysis. The results of the study show that there is a significant long-run and short-run influence of VAT and other tax revenues on Nigerian Gross Domestic Product (GDP). However, the Granger causality test result shows that the growth in GDP drives VAT and revenue growth in Nigeria without a feedback.

\subsection{Thechallenges militating against increasing the tax-to-GDP ratios ofSub-Sahara African Countries}

To-The following challenges to increasing the tax-GDP ratios are common to mostsubSahara African countries, paticularlyNigeria : -

(a)Generally, the objectives of a good tax system, such as economic efficiency, effectiveness and equitability,are frequently in conflict with each other. In addition, progressive taxesin highly unequal societies are difficult to achieve.

(b)Up to $80 \%$ of the workforce in African countries are outside the formal labor force( see Pirtilla, 2018) . Even though taxation can be carried out in several ways, one of the most important components of modern tax system is income tax.This kind of tax is deducted from wages and salaries. Income taxation facilitates a broad tax base that is difficult to evade. Unfortunately, only about $20 \%$ of the workforce in sub Sahara Africa can be subjected to paying income tax.

(c)There is hardly any taxation in Africa. Aid appears to be the only external financial inflow to Africa. Generally,African countries have the tendency to always dependent on financial aid. For instance,according to Pirtilla (2018), foreign aid to African nations amounted to USD 104 billion (from OECD-DAC countries) and USD 8 billion (from non-DAC donor countries) in 2007 alone.In addition,the foreign direct investments in Africa in 2008 was approximately USD 88 billion. This amount was mostly shifted to extractive industries and the beneficiaries were Nigeria, Angola, Egypt and South Africa.

(d)Tax reforms are hardly on the policy agenda in African countries,

eventhough there are improvements in their tax systems such as simplification of the tax system, improved tax administration at the central government level and improved attitudes of tax administration towards some segments of taxpayers, 
(e)The problem of tax administration is systemic. One of the major problems is fiscal federalism - the problem ofwhich arm of government collects which tax? Thus, tax jurisdiction problem creates room for tax avoidance and evasion as neither the federal nor state government ends up benefiting from the tax revenue. Another fiscal issue is the problem of multiple taxation which subjects one and same tax base to two or more different multiple taxes. This also creates room for the taxpayers to evade or avoid paying taxes.

(f) The corruption in tax administration is tripartite. One is corruption by the taxpayers where correct tax amounts are not declared. Consequently, lower taxes are paid to the relevant tax authorities. The second is the corruption on the part of tax authorities where tax collectors connive with the tax payers to shortchange the government. This usually happens with the taxpayers being issued clean tax clearance certificates unduely. The third borders on insicerity and fraud onthe part of the government itself.The revenue generated from the taxation is often not utilized to the benefit of the taxpayers but stolen from the government purse. This creates apathy in the taxpayers who,as a result,employ all available means to minimize their tax liabilities.

(g)Revenue shock arising from trade liberalization. For some time in the past, economists have considered trade liberalization as a central component of growth and development. The understanding is thatas increased trade and capital flows spur growth, the loss in tax revenues from trade is expected to be easily compensated with the taxes collected from a more dynamic private sector. Consequently, trade liberalization in the developing world is accepted as a necessary step in the path to development success. However, this rosy view notwithstanding, many developing countries have been facing formidable challenges in recovering from the revenue shock and substituting their lost trade tax revenues with domestic taxes (see Rudra \& Bastracus,n.d).The end result is that liberalizing trade has translated into a large and rapid loss of trade tax revenues for governments across the subSahara African countries.

(h)A large percentage of citizens (and firms) in poor economies like those in sub-Samara Africa are logistically difficult to tax.

(i)There exist weak bureaucracies and obsolete technologies in African countries.

(j)Difficulty in engaging in tax reform in the liberalizing environment as governments find themselves in a dilemma

Governments face rising political pressures to keep domestic taxes low so that lessproductive firms can survive in the face of international market competition. At the same time, even more-productive exporting firms are demanding lower tariffs.

(k)Generally, taxation is low on the domestic political agenda of most sub-Sahara African countries.

(1) Most often, the political and economic elite are not part of the tax base.A lot of people do not pay tax.The few that pay tax pay paltry sums to enable then get tax clearancecertificates.

(m)The tax bases in most African nations are astronomically narrow. 
One of the major causes of the low rate of tax revenue to GDP in sub-Sahara Africa is narrow tax base.For instance, out of estimated 200 million people in Nigeria, the World Bank put the economically active population at 65 million. Out of this amount, the federal government claims to have increased the taxpayer's population from 10million to 20 million (see Oladipo and Ogochukwu (2019). Thisputs the percentage of active tax payers at 31\%. This implies lack of efficiency in tax administration and results tomounting undue pressure on the few active tax payers who are compelled to payhigher taxesforgovernmentsto meet their revenue targets.

(n)Massive loss of revenues from natural resources in sub-Sahara African nations.

(o)Illicit capital flows facilitated by tax havens. This has contributed significantly in entrenching inefficient tax systems in sub-Sahara Africa.

.(p)Poor taxation of the informal sector of the economy.

(q) In Nigeria particularly, a lot of tax revenues are lost as a result of oil pipeline vandalism and illegal crude oil bunkarings

As noted in the IMF(2018)'s working paper on informal economy in sub-Saharan Africa, it is estimated that the informal sector accounts for between $50 \%$ and $65 \%$ of economic activities in Nigeria. Business concerns in the informal sector hardly pay taxes. They rarely remit other taxes such a value added tax and withholding tax to the relevant authorities. Thus, there is a high level of tax leakages which would have significantly contributed to the loss of revenue in the country.

(r) Low level of tax education

The general literacy rate in Nigeria is stated at 50\%. The level of tax education is expected to be lower than this as tax issuesare sometimes very complex. Many tax payers do not know the various taxes they are expected to pay. Many small and medium enterprisesin Nigeria as well lack the professional knowledge on tax computation and remittance. There is also a high level of non-remittance of withholding taxes in the Nigerian tax system.

(s)High level of tax expenditures

One of the factors contributing to the low level of tax revenue is high level of tax expenditure. Tax expenditure comprises of the reliefs and allowances granted to businesses or to individual taxpayers in a form of social scheme. Though some of the allowances are given as social benefits, they are supposed to be revenue to the government which the taxpayers enjoy directly without the revenue authorities accounting for them directly as a tax income. This implies that the countries that do not allowsuch allowances and reliefs will have higher tax revenue. For example, companies engaging in manufacturing and agricultural production pay only $20 \%$ of their accessible profit for the first four years. Thisrelief could have constituted revenue for the government. Nigeria allows for too many deductions and reliefs which contribute to lower tax revenue and,consequently, low tax-to-GDP ratio.

(t)Under-utilized excisetaxrevenue

According to IMF (2018), excises on alcohol, tobacco, fossil fuels, motoring and environmental degradation (such as littering and pollution) are among the most important 
import pillars of tax revenue systems around the world.Several considerations underpin the wide use of excise taxation,viz (a) Excises on smoking, abusive drinking, and environmental degradation are imposed on their consumers to internalize the external costs (physical, financial, psychological) that the consumption of such products and activities impose on the society.In this way, an efficient allocation of resources is promoted. (b) Excises on items of luxury goods consumption and airtime may be used to promote progressivity in taxation; (c) Excises on motor fuel and motor vehicles can be rationalized as proxies for the cost of government-provided road services and the external costs (pollution, congestion) imposed on other people. (d) The marginal cost of collecting excise duties is much lower than that of all other taxes, including the VAT. In Nigeria, excises yield little revenue and do not fulfill their role in internalizing the negative external costs of use or consumption. At current levels, excises contribute less than $2.3 \%$ of total tax revenue or about 0.04 percent of GDP-a situation which contrasts sharply with those of other countries where excise duties contribute on average $12.3 \%$ of total tax revenue (more than 5 times higher than Nigeria or 3.2 percent of GDP (seeTable 3 in appendix E). On a comparative basis, it should be possible therefore to triple or quadruple excise tax collections in Nigeriaas per table 3.According to International Monetary Fund Report (2018), the excise taxation base in Nigeria is relatively narrow. The Federal Government taxes only tobacco products and alcoholic beverages, independent of alcohol content, at a rate of 20 percent (see Table 4 in appendix E). Petroleum products are not taxed, while states tax motor vehicles. Other products, such as non-alcoholic beverages, fruit juice, and telephone recharge cards, were subject to a 5 percent excise before their removal in 2009. Following the British tradition, Nigeria does not levy excise duties on imported excisable goods, but subsumes these in the import duty.

\section{Way foward:Lessons from advanced economies}

While highlighting the options for revenue mobilization inNigeria, $\operatorname{IMF}(2018)$ reports that low non-oil revenue mobilization is affecting Nigerian government's objectives to expand growth-enhancing expenditure priorities, ensure higher growth and employment, and keep to its fiscal rule which limits its deficit to a maximum of 3 percent of GDP. IMF acknowledgesthat there is significant revenue potential from structural tax measures.However, the apex monetary authority insists that a broad-based and comprehensive tax reform program, is required in Nigeria in the short and medium term to address these objectives and generate sustainable revenue growth, as has been done inmany advanced economies,.IMF(2018) claims that Nigeria will achieve this objective by broadening the bases of income and consumption taxes.In addition, the countryis advised to close the loopholes and leakages created by the current corporate tax holidays and the widespread use of other associated tax expenditures.At the same time, it will have to provide conducive environment for the States and local governments to raise their own revenue sources.In summary,IMF (2018) suggests the following reforms in the Nigerian tax system taxaimed at strengthening its revenue-raising efficiency and externality:-

(a)Converting ad-valorem excises on alcohol and tobacco to specific (and higher) rates indexed for inflation to reflect the external costs of consumption and production.

In line with international practice and what advanced economies do, tobacco excises could be more than doubled in real terms, imposed at NGN 100/pack of cigarettes of 20 over a threeyear period (with equivalent duty for other tobacco products). Alcohol excises could be linked to alcohol content (beer, wine, and spirits) and increased in value. For example, doubling the excise duty on beer would align it with the current Kenyan excise burden. 
(b)Recognizing the function of environmental charges in increasing resource efficiency and revenues. This could be achieved through giving more attention to environmental taxation.Specific consumer charges can be imposed on the use of plastic shopping bags, plastic bottles, aluminum cans, and incandescent light bulbs (for example, a waste packaging charge of NGN 5 per plastic bag). To compensate for the cost of global air pollution (carbon dioxide, methane, nitrous oxide) and its contribution to climate change, a low-rate excise charge of NGN 10/liter could be imposed on all fossil fuels (gasoline, diesel and kerosene)

(c)Contributing to the cost recovery of road transport infrastructure.In addition to air pollution, road users create multiple externalities in the form of road damage, particularly by heavy trucks; congestion, which carries an implicit tax on labor; and noise and accident costs. Consumers would make better decisions regarding their use of the road network if such costs were internalized in the price of fuel. For example,this can be perfected by introducing an additional motoring fuel duty on gasoline and diesel products (NGN 10/liter on leaded gasoline and diesel fuel, NGN 5/liter on unleaded gasoline). Since kerosene is mostly used by poorer households for cooking, heating and lighting, kerosene could be exempted from this additional excise duty on motoring.

(d)Improving tax progressivity by increasing excise duties on luxury goods and air time. This could be achieved by increasing excise duties and motor vehicle license fees on cars (new and imported) while proceeding with preparations for introducing a low charge on mobile phone use (airtime) on call minutes and SMS.

(e)Providing a level-playing field for the internalization of external costs by levying excise duties at equal rates on domestically produced and imported goods. A reform of excise taxation would correct the current policy of subsuming excise on foreign goods in the import duty. This would make the protective function of the tax system the exclusive prerogative of the import duty regime, while allowing excise duties to serve as an allocative function irrespective of whether the products originate domestically or from abroad. As donein advanced countries, VAT should be imposed on the excise (and import) duty-inclusive value of excisable items.

(f)Converting ad-valorem excises into a specific rate system. This is supported by both theoretical and practical considerations. Economic theory favors the correction of externalities through specific duties over ad-valorem taxation as the external costs on the society of smoking, drinking, motoring, and polluting are independent of the underlying products sales price. In practice, excises provide the authorities with the opportunity to increase revenues without major administrative costs associated with a new ICT system development or the hiring of additional staff. As specific duties require only counting (e.g., cigarettes) or measuring strength (alcoholic beverages) or volume (e.g., of motor fuels), they pose no contentious valuation issues relating to unit cost or unit value at the manufacturing or the importation stage. To preserve the real value of excise revenue, specific duties would need to be indexed for inflation through annual adjustments. Gradual excise duty increases at the prevailing ECOWAS levels could yield revenues of $2.5 \%$ of GDP in the medium term, and of about $4 \%$ of GDP in the long run. In the medium term, a comprehensive review should be made of all taxes, duties, levies and charges on road transport, broadly defined. Such a review should have regard not only for revenue-raising efficiency aspects and externality correcting issues, but also for distributional incidence aspects (as discussed on the 
distributional aspects of fiscal reform). The review should be undertaken in cooperation with the Nigerian States and the Federal Road Authority.

In addition to theremedies advanced by $\operatorname{IMF}(2018)$ on the ways to address the challenges identified,the Nigerian government and other sub-Sahara African countries need to take the following additional steps;-They should

(a)consider improving the existing tax system with a view to reducing inequalities through(i)raising additional revenue through indirect taxes; (ii)focusing on tax reforms that would simultaneously facilitate revenue growth, build administrative capacity and build accountability;(iii)improving theirlocal government taxation;(iv)levying taxes as consensually and transparently as possible;(v)supporting civil society groups' capacity to engage with the countries on tax issues;(vi)making tax strong on the domestic political agenda (vii)carrying out tax informality surveys and surveys of taxpayer perceptions to identify willingness to pay issues aroundinequality and social injustice,(viii)establishing better links between taxes paid and service delivery, and (ix)intensifying efforts to stop oil theft and illogical oil bunkering

In addition, the sub-Sahara African governmentsare advised to provide tax reforms that would (i)reduce tax exemptions or eliminate them completely;(ii)tackle capital flight aimed at evading taxation;(iii)strengthen the administration of natural resources taxation, especially in extractive industries;(iv)improve progressivity through income tax and property taxes;(v)seek for more effective ways to tax the informal sector;(vi)put in place a simplified tax regime for micro and informal sector,and (vii)establish a dedicated tax unit for Small and Medium enterprises.

Further, Nigeria and other sub-Sahara African nations should urgently strive to replace almost a third of their already low tax revenue base with 'hard to collect' domestic taxes.

Secondly, the efficient use of tax clearance certificates for transactions by all the countries in the sub-Sahara African region is also advisable.

\subsection{Conclusion}

This study had the primary objective of identifying the challenges militating against the growth of tax-to-GDP ratios of Sub-Sahara African countries, their causes and remediesIt used Nigeria as a case study while the content analysis research approach was adopted.The paper observes thatthe low- rated countries are characterized by Gulf countries while the high rated ones are dominated by European countries. It equally observes that, even as one the largest economies in Africa, Nigeria is one of the sub-Sahara Africancountries having the lowest tax-to-GDP ratios.Most fiscal experts, almost regardless of political stance, seem to agree that the best way for developing countries to respond to the tax challenges they face are essentially three,namely, broadening tax bases (especially of consumption taxes), reducing rates (especially of income taxes), and improving tax administration.Based on a few lessons that can be drawn from countries that have been successful in the past,sub-Sahara African countries should put in place an unambiguous political mandate to tackle low levels of tax payment, a simpler tax system with a restricted number of rates and exemptions,impose more taxes on goods and services and boost tax collection by employing modern technologies.

\section{References}

1. Abdulazeez, D. A. \& Dandago, K. S. (2018). Impact of Non-Oil Tax Revenue on Economic Growth of Nigeria.Economy \& Finance;1-18.International Centre for Tax and Development - ICTD 
2. Adam, S.(1776). The Wealth of Nations: A Translation into Modern English, ISR/Google Books, 2015. Book 5 (Government Finances: Public Expenditure, Taxation and Borrowing), 423- 429. Ebook ISBN 9780906321706

3. Anakoya,S., \& Afintini, D. (2016).Taxation and Economic Growth in Nigeria. Asian Journal of Economic Modeling. Pp. 199 - 210.

4. Bassey, O.U (2013). Companies income taxation in Nigeria; CIBN Press Ltd Lagos Benk,

5. Bird, R.M. (2008) "Tax Challenges Facing Developing Countries" Inaugural Lecture of the Annual Public Lecture Series of the National Institute of Public Finance and Policy, New Delhi, India, March 12.

6. Coulibaly,B.S. \& Gandhi,D.(2018). Mobilization of tax revenues in Africa

7. State of play and policy options. Policy Brief Africa Growth Initiative.1-14.

8. Eze, O. M.; Udude, C. C. \& Atuma, E.(2018).Re-Evaluation of The Economic Impact of Tax Policy on The Growth of Nigerian Economy, IOSR Journal of Economics and Finance (IOSR-JEF) $e$ - ISSN: 2321-5933, p-ISSN: 2321-5925.9( 2). 61-74 www.iosrjournals.org DOI: 10.9790/5933-0902016174

9. Ezeji E.; Chigbu, P. \& Ali,I. (2014) Econometrics Analysis of the Impact of Value Added Tax on Economic Growth of Nigeria. European Journal of Business and Management.

10. FISCALIS Tax Gap Project Group (2018,July).The concept of tax gaps report ii: corporate income tax gap estimation methodologies.FISCALIS 2020 EUROPEAN COMMISSION TAX GAP PROJECT GROUP DIRECTORATE-GENERAL TAXATION AND CUSTOMS UNION, Brussels

11. Folajimi, F., Olajumoke, J., \& Jerry, K. (2016). Assessment of Value Added Tax on the Growth and Development of Nigeria Economy: Imperative for reforms. Research Journal of finance and Accounting.

12. Heritage Foundation(2015).Economic data and statistics on world economy.www.heritage.org/index/explore?view=by-variables

13. International Monetary Fund (2018) IMF Country Report No. 18/64 Nigeria Selected Issues.

14. Iyalode, A. L.(2019).Understanding tax and its effect on ngerian businesses, Tax conference organised by NACCIMA in Lagos in partnership with the Lgos Internal Revenue Services and the Federal Inland Rvenue Services .Lagos, Nigeria. Sptember,

15. James, S. \& Nobes, C. (1992) Taxation: Theory and practice. London, Prentice Hall.

16. Kalaš,B.,Mirović,V. \& Milenković,N.(2018). The relationship between taxes and economic growth:Evidence from Serbia and Croatia,European Journal of Applied Economics, DOI: 10.5937/EJAE15-18056.15(2);17-28.

17. Kagan, J. (2019).Tax-to-GDP Ratio. Fiscal Policy Tax Laws . Jul 14

18. Kolade, T.\& Ajogbor, P.(2019).Nigeria: Nigeria's unchanging Tax To GDP Ratio: An instructive appraisal. Andersen Tax LP 25 September.

19. Lawrence, K. (2015). The Effect of Value Added Tax on Economic Growth in Kenya. International Academic Journal of Economics and Finance pp. 10 - 30.

20. Lipsey, R.G. \& Chrystal, K.A. (2011) Economics (12 ${ }^{\text {th }}$ ed). New York: Oxford University Press inc. .

21. Manukaji, I. J. \& Nwadialor, E. O. (2016). Assessment of the contribution of value added tax to the Nigerian economy. International Journal of Social Sciences and Management Research, 2 (1), 45-56.

22. Mazur, M.J. \& Plumley, A.H. (2007).Understanding the Tax Gap. National Tax Journal,LX(3); 560-577.September 
23. Muley, R. (n.d) Taxation objectives: Top 6 objectives of taxation - discussed! Economics discussion Taxation Objectives \%20 Top 6 objectives of Taxation - Discussed! Htm. Accessed 10/06/2019.

24. National Bureau of Statistics (2018). Nigerian GDP Report Q2 2018, FIRS 2018 Q2 Revenue Collection Statistics

25. Nightingale, K. (2001). Taxation: Theory and practice. London, Prentice Hall.

26. Obatola, O.S. (2013). The rudiments of Nigeriantaxation. Yaba Lagos: ASCO Publishers

27. Odhiambo,O. \& Olushola, O. (2018). Taxation and Economic Growth in a Resource-Rich Country: The Case of Nigeria. http://dx.DOI: 10.5772/intechopen.74381

28. Odusola, J. A. (2016). Taxpayer compliance: Social science perspectives. Philadelphia: University of Pennsylvania Press.

29. Okwara, C. C. \& 2Amori, O, M.(2017). Impact of tax revenue on economic growth in Nigeria,International Journal of Advanced Scientific Research | IJASRInternational Journal of Scientific Research in Social Sciences \& Management Studies, 25791928,2(2);90-102

30. Oladipo, M. \& Ogochukwu, I. (2019). Nigeria: Nigeria's unchanging tax-to-gdp ratio. Anderson Tax. Accesses 10/06/2019.

31. Oyewo, B. (2013). Taxation and Tax Policy as Government Strategy Tool for Economic Development in Nigeria. IOSR Journal of Business and Management. Vol. 13.

32. Ubesie M. C., Igweonyia O. V. \& Ozo-Ubaka, C. J.,(2019). A Causal and Long-run Nexus Between Value Added Tax and Economic Growth of Nigeria (1994-2017), International Journal of Finance and BankingResearch.5,(.6);145-153.doi: 10.11648/j.ijfbr.20190506.13

33. Webber, C. \& Wildasky, A (1986) A history of taxation andexpenditure in the Western World New York: Simon and Schuster. World Bank and International Finance Corporation (2018) Paying Taxes 2018 Washington, DC.

34. Fjeldstad, O. (2011). Taxation for development: Myth, facts and challengesforAfrican countries. Chr Michelsen Instituteand International centre for tax anddevelopment.w.w.w.CMI.Addressing Inequality. TFESSD Conference, Oslo,31May.

35. Pirttila, J. (2018). Solving the challenges of taxation in developing countries.University of Helsinki. Society and Economy.November 20.

36. Rudra, N.\& Bastacus, I. (n.d.). Challenges of taxationand re-distribution inglobalizing economies.

37. Wikipedia (2019,September).List of countries by tax revenue to GDP ratio.shttps://wiki2.org/en/List_of_countries_by_tax_revenue_to_GDP_ratio

APPENTIX A

TABLE 1: TAX-GDP-RATIO OF SELECTED COUNTRIES

Low Rated TGR Countries
\begin{tabular}{|l|l|l|l|l|l|}
\hline S/N & COUNTRY & TGR Rate & S/N & COUNTRY & TGR Rate \\
\hline 1 & United Arab Emirates* & 1.4 & 1 & Algeria & 64.07 \\
\hline 2 & Kuwait* & 1.5 & 2 & Timor-Leste & 61.5 \\
\hline 3 & Equatorial Guinea & 1.7 & 3 & Norway & 54.8 \\
\hline 4 & Oman & 2 & 4 & Finland & 54.2 \\
\hline 5 & Qatar* & 2.2 & 5 & Denmark & 50.8 \\
\hline 6 & Libya & 2.7 & 6 & Sweden & 49.8 \\
\hline 7 & Chad & 4.2 & 7 & Belgium & 47.9 \\
\hline 8 & Baharin & 4.8 & 8 & France & 47.9 \\
\hline
\end{tabular}


Available online on http://rspublication.com/IJRMF/IJRMF.html Volume 4 Issue 1(January- February 2020)

\begin{tabular}{|l|l|l|l|l|l|}
9 & Myanmar & 4.9 & 9 & Cuba & 44.8 \\
\hline 10 & Saudi Arabia* & 5.3 & 10 & Germany & 44.5 \\
\hline 11 & Republic of Congo & 5.9 & 11 & Italy & 43.5 \\
\hline 12 & Iran & 6.1 & 12 & Lesotho & 42.9 \\
\hline 13 & Nigeria & 6.1 & 13 & Austria & 42.7 \\
\hline 114 & Suda & 6.3 & 14 & Bosnia and Herzegovina & 41.2 \\
\hline 115 & Afganistan & 6.4 & 15 & Iceland & 40.4 \\
\hline
\end{tabular}

\section{Source: Heritage Foundation (2016)}

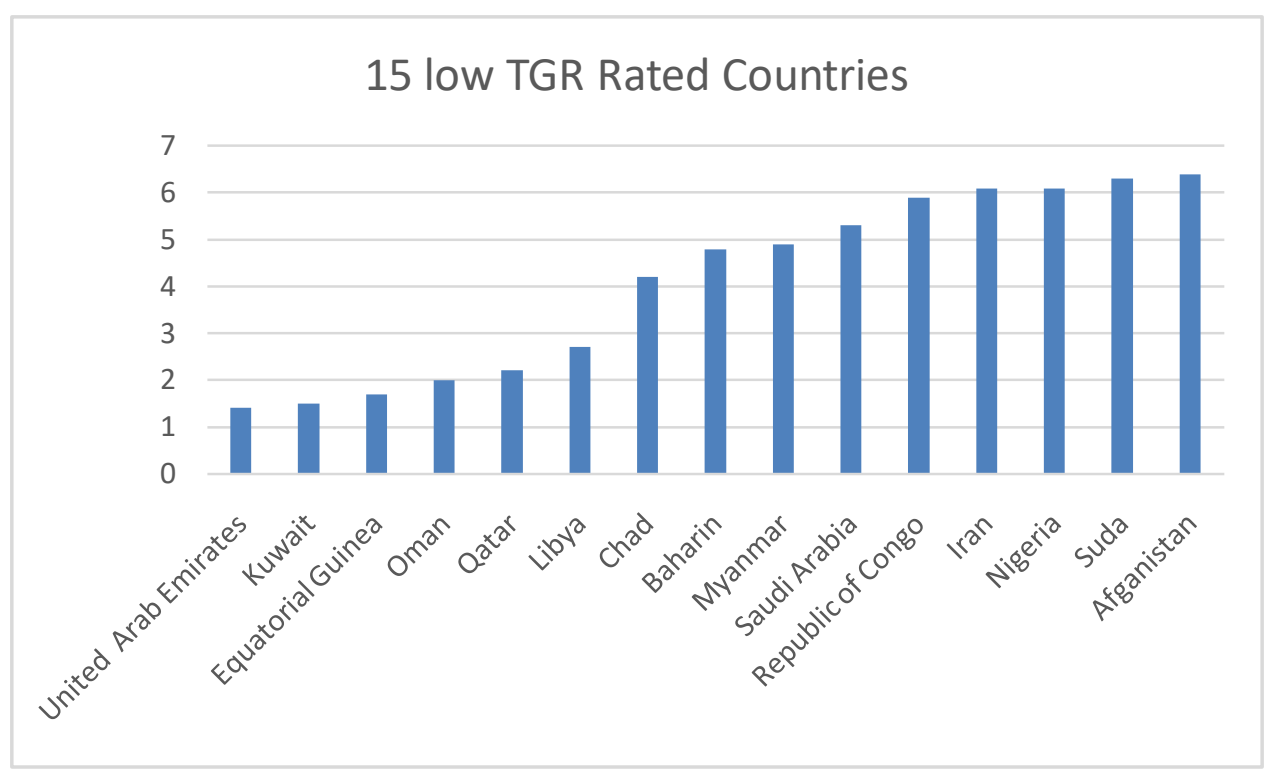

Figure 1: Tax-GDP-Ratios of 15 low rated countries

APPENDIX B:The bar chart of selected African countries and OECD average

\section{Selected African Countries and OECD TGR}

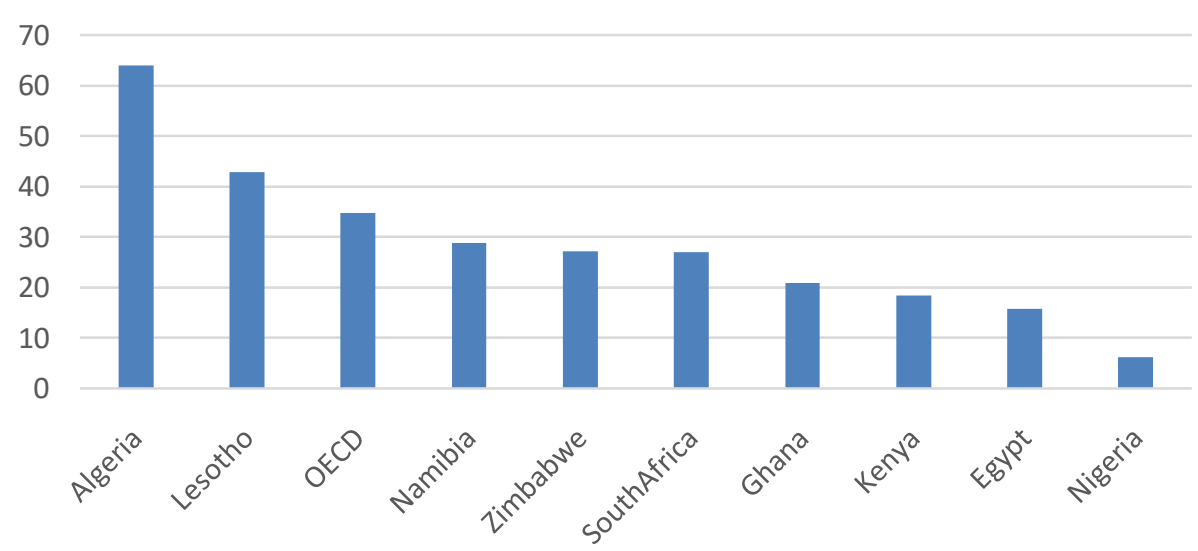

Figure 3: Tax-GDP-Ratio of Selected African Countries 
International Journal of Research in Management Fields

ISSN (P) 2577-1876 (O) 2577-4274

Available online on http://rspublication.com/IJRMF/IJRMF.html Volume 4 Issue 1(January- February 2020)

\begin{tabular}{|c|c|c|c|}
\hline APPENDIX C: & GDP (N'Billion) & Tax Revenue (N'Billion) & Tax-GDP-Ratio \\
\hline 2004 & $35,020.55$ & $1,194.80$ & 3.41 \\
\hline 2005 & $37,474.95$ & $1,741.80$ & 4.65 \\
\hline 2006 & $39,995.50$ & $1,866.20$ & 4.67 \\
\hline 2007 & $42,922.41$ & $1,846.90$ & 4.30 \\
\hline 2008 & $46,012.52$ & $2,972.20$ & 6.46 \\
\hline 2009 & $49,856.10$ & $2,197.60$ & 4.41 \\
\hline 2010 & $54,612.26$ & $2,839.30$ & 5.20 \\
\hline 2011 & $57,511.04$ & $4,628.50$ & 8.05 \\
\hline 2012 & $59,929.89$ & $5,007.70$ & 8.36 \\
\hline 2013 & $63,218.72$ & $4,805.60$ & 7.60 \\
\hline 2014 & $67,152.79$ & $4,714.60$ & 7.02 \\
\hline 2015 & $69,023.93$ & $3,741.80$ & 5.42 \\
\hline 2016 & $67,931.24$ & $3,307.50$ & 4.87 \\
\hline 2017 & $68,490.98$ & $4,027.94$ & 5.88 \\
\hline 2018 & $69,810.02$ & $5,320.52$ & 7.62 \\
\hline Average & 55264.19 & 3347.531 & 5.860899 \\
\hline St.Dev & 12520.62 & 1370.218 & 1.555953 \\
\hline
\end{tabular}

Source: Central Bank of Nigeria (2019)

APPENDIX D:The graph of GDP growth and total tax revenue growth rate from year 2004 to 2018

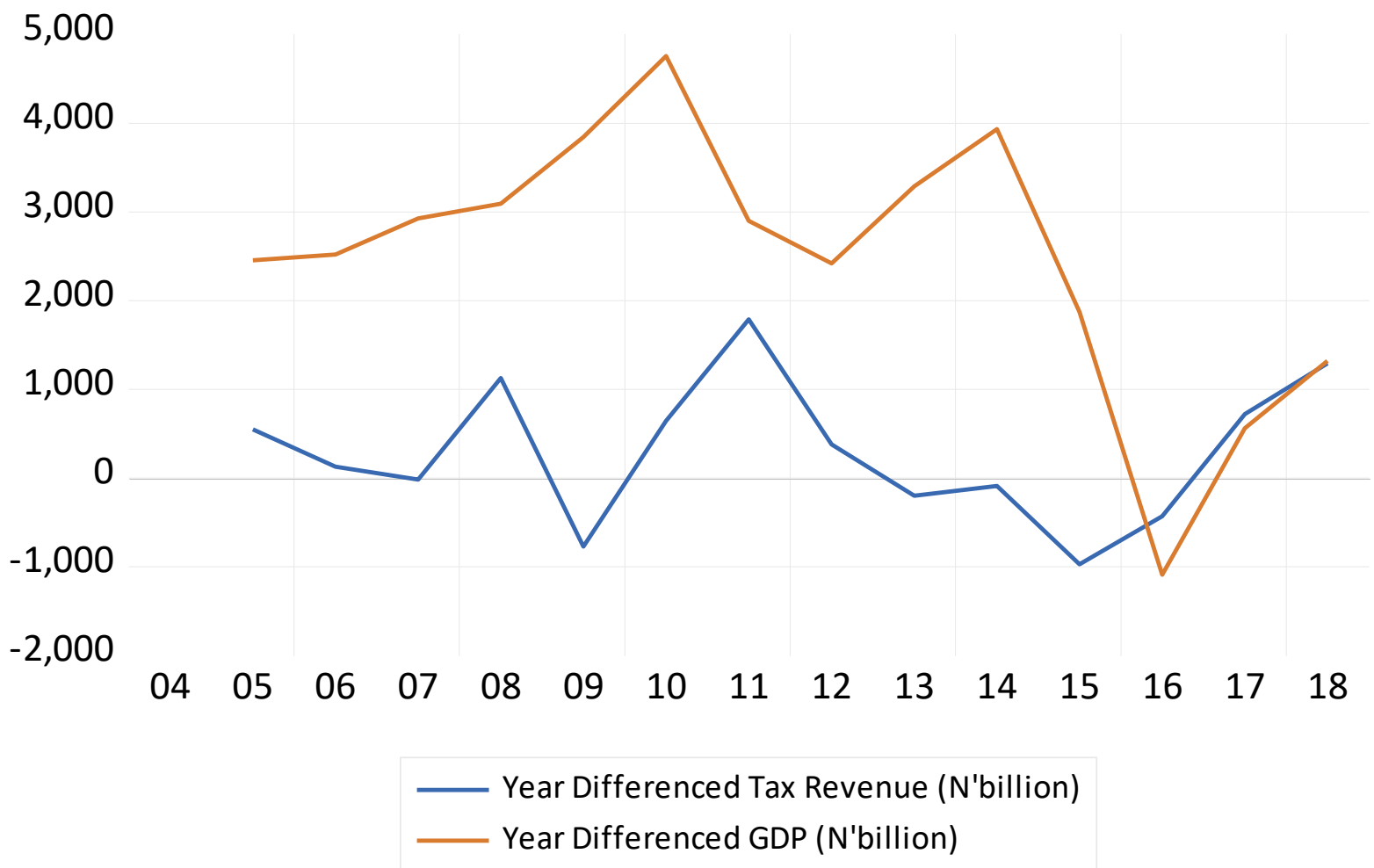

Figure 4: Graph of GDP and Tax Revenue growth of Nigeria 
Tax to GDP Ratio

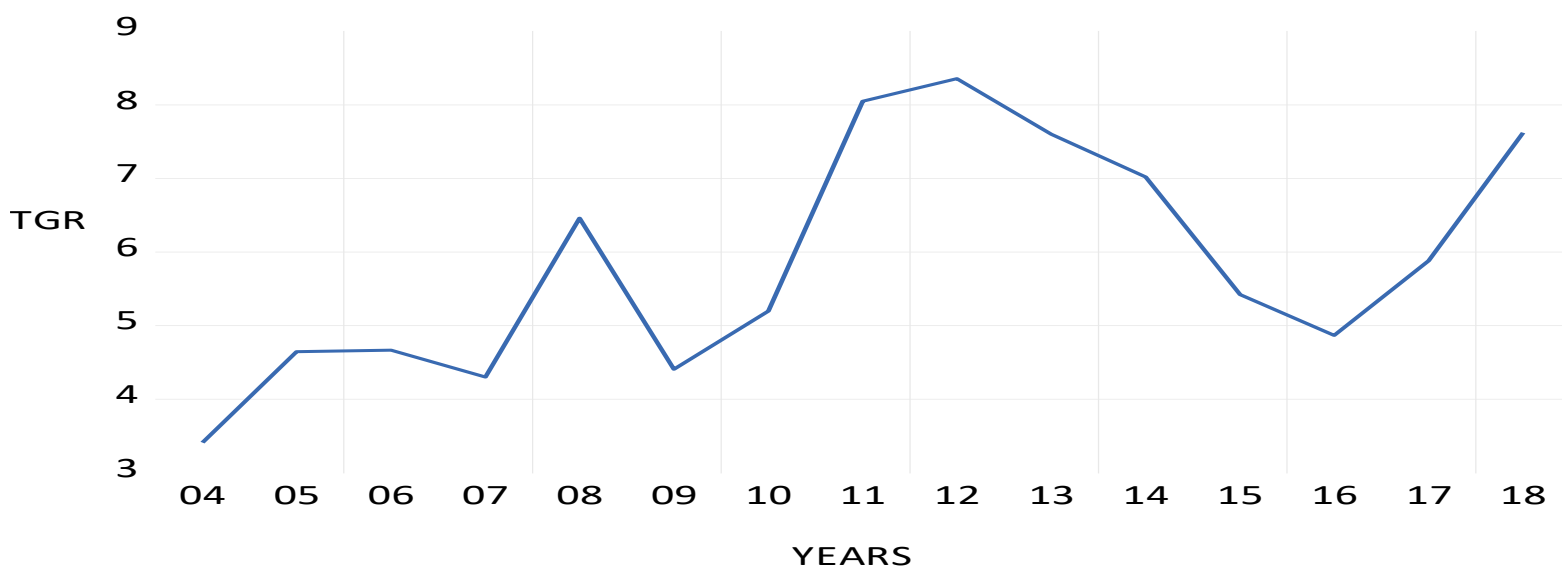

Figure 5: Tax-GDP ratio growth of Nigeria

Figure 2: Tax-GDP-Ratio of 15 top TGR rated countries

APPENDIX E:Nigeria: Excise Collections (2016) and Selected Countries (2014)

Table 3 Nigeria: Excise Collections (2016) and Selected Countries (2014)

\begin{tabular}{|c|c|c|c|}
\hline \multirow[t]{2}{*}{ Countries } & \multirow{2}{*}{$\begin{array}{c}\text { Total Tax, as } \\
\text { percentage of GDP }\end{array}$} & \multicolumn{2}{|c|}{ Excise Duty Revenue, as percentage of: } \\
\hline & & GDP & Total Tax \\
\hline Nigeria (Non-oil) & 4.1 & 0.1 & 2.3 \\
\hline Ghana & 15.3 & 1.7 & 11.0 \\
\hline Kenya & 19.5 & 2.9 & 14.9 \\
\hline South Africa & 27.9 & 3.5 & 12.2 \\
\hline Australia & 27.6 & 3.2 & 11.4 \\
\hline Canada & 31.9 & 2.9 & 9.2 \\
\hline United Kingdom & 32.5 & 2.4 & 7.3 \\
\hline United States & 26.4 & 2.3 & 8.7 \\
\hline Turkey & 30.0 & 6.4 & 22.2 \\
\hline
\end{tabular}

Source: IMF (2018).

APPENDIX F:Nigeria Excisable Goods, Excise and Duty Rates (Percentage)

\begin{tabular}{|c|c|c|c|c|c|}
\hline Duty or Tax & Cigarettes & Beer & Wine & Spirits & Tax Base \\
\hline Import Duty (ID) & $20 \%$ & Prohibited & $20 \%$ & $20 \%$ & CIF Value \\
\hline Levy & $50 \%$ & N/A & $50 \%$ & $50 \%$ & $\mathrm{CIF}+\mathrm{ID}$ \\
\hline Port Development Surcharge & $7 \%$ & N/A & $7 \%$ & $7 \%$ & $\mathrm{CIF}+\mathrm{ID}$ \\
\hline $\begin{array}{l}\text { Comprehensive Import } \\
\text { Supervision Scheme }\end{array}$ & $1 \%$ & N/A & $1 \%$ & $1 \%$ & $\mathrm{CIF}+\mathrm{ID}$ \\
\hline Total effective duty at import & $89.6 \%$ & N/A & $89.6 \%$ & $89.6 \%$ & $\mathrm{CIF}+\mathrm{ID}$ \\
\hline $\begin{array}{l}\text { Total effective duty and tax on } \\
\text { CIF value }\end{array}$ & $94.1 \%$ & N/A & $94.1 \%$ & $94.1 \%$ & \\
\hline Excise duty & $20 \%$ & $20 \%$ & $20 \%$ & $20 \%$ & Unit cost \\
\hline VAT & $5 \%$ & $5 \%$ & $5 \%$ & $5 \%$ & Unit cost + Excise \\
\hline $\begin{array}{l}\text { Total effective duty on pre-tax } \\
\text { value }\end{array}$ & $26 \%$ & $26 \%$ & $26 \%$ & $26 \%$ & \\
\hline
\end{tabular}

